\title{
Towards a Democratic New Normal? Investor Reactions to Interim-Regime Dominance during Violent Events
}

\section{Omar El Nayal $^{\mathrm{a}}$, Arjen Slangen ${ }^{\mathrm{b}}$, J. (Hans) van Oosterhout ${ }^{\mathrm{c}}$ and Marc van Essen ${ }^{d}$}

${ }^{a}$ Universidade Católica Portuguesa; ${ }^{b}$ KU Leuven; ${ }^{c}$ Erasmus University; ${ }^{d}$ University of South Carolina

ABSTRACT Although interim regimes in former autocracies are generally tasked with initiating a democratic 'new normal', they may privately intend to become their country's new autocratic rulers. We argue that, to cope with the uncertainty stemming from this possibility, investors infer an interim regime's intentions from the dominance displayed by the regime during governmentrelated violence, as reflected in the share of civilian fatalities. Specifically, we propose that investors interpret higher interim-regime dominance as a signal of weaker democratic intentions and associate such weaker intentions with a gloomier political outlook for local firms. We therefore hypothesize that investors react more negatively to violent events characterized by higher interim-regime dominance. We also hypothesize a less negative effect of such dominance for firms with larger foreign footprints, lower indebtedness, or more concentrated ownership, since investors will likely consider such firms more resilient to political deterioration. Applying event study methodology to 94 spells of violence in Egypt during the Arab Spring, we find substantial support for our hypotheses, thus contributing to management research on investor decisionmaking, violence, and political uncertainty.

Keywords: event study, government-related violence, interim-regime dominance, new normal, political uncertainty, signals

The fall of long-standing despots (...) is a necessary part of any transition to democracy. But it can also start a civil war, or lead to a new dictatorship as the next strongman builds his own networks of power

The Economist (2019, p. 54) in response to the fall of Sudan's autocratic leader Omar al-Bashir on 11 April.

Address for reprints: Marc van Essen, Darla Moore School of Business, University of South Carolina, 1014 Greene St, Columbia, SC 29208 (marc.vanessen@moore.sc.edu) 


\section{INTRODUGTION}

Many management studies have explored how firms are affected by the actions and policies of national governments (e.g., Malik and Kotabe, 2009; Sun et al., 2015). In general, these studies focused either implicitly or explicitly on conventional types of governments in the form of democracies and autocracies (Alvarez et al., 1996). However, over the past 70 years more than 40 countries have at some point had a different type of regime namely, an 'interim' one (Geddes et al., 2014; Guttieri and Piombo, 2007).

Interim regimes are especially common in countries that have just experienced a collapse of autocratic rule. In such countries, interim regimes are generally tasked with initiating a transition to a so-called 'new normal', broadly defined as economic, political, or social conditions that are fundamentally different from the traditional state of the environment (Ahlstrom et al., 2017; Hitt et al., 2016). More specifically, interim regimes in former autocracies are typically tasked with initiating a new normal of democratic governance by organizing free and fair elections and handing over power to the elected officials shortly afterwards (Geddes et al., 2014; Seely, 2009).

Although interim regimes in former autocracies often claim to be committed to their task of initiating a democratic new normal, they may privately intend to become their country's new autocratic rulers (Pevehouse, 2005). Examples of countries that have had such untrustworthy interim regimes include Algeria, Brazil, Chile, Cuba, Ethiopia, Nicaragua, Nigeria, and Yemen. The interim regimes of these and other countries at some point during their tenure announced that they had decided to prolong their rule, often under the pretence of 'national interest' (Shain and Linz, 1995). Since interim regimes may develop the private intention to become autocratic rulers at any point during their tenure, potential and actual investors in local firms face substantial political uncertainty during interim periods. To cope with this uncertainty, investors will likely attempt to obtain information on an interim regime's political intentions throughout its tenure, but how exactly they do so has remained unclear.

In this study, we combine insights from the behavioural perspective on investor decision-making (e.g., Schijven and Hitt, 2012) with political science research on regimes' use of violence (e.g., Davenport, 1999, 2007) to propose that investors infer an interim regime's political intentions during its tenure from crude pieces of public information, or 'signals'. Specifically, we argue that investors infer these intentions from the share of civilian fatalities in the total death toll resulting from events of government-related violence in the country, a share that we refer to as the 'dominance' shown by the interim regime. We argue that investors interpret higher interim-regime dominance during a given violent event as a signal that the regime has weaker democratic intentions at that time, and that investors associate such weaker intentions with a more adverse political outlook for local firms. We therefore hypothesize that violent events characterized by higher interim-regime dominance are received more negatively by the local stock market.

Furthermore, we argue that investors use pieces of information on individual firms as signals of a firm's resilience to the adverse political developments that may result from high interim-regime dominance. Specifically, we contend that investors consider this resilience to be higher among firms with larger foreign footprints, lower indebtedness, or more concentrated ownership structures. For such firms we therefore hypothesize the 
negative relationship between an interim regime's dominance during a violent event and the stock market's reaction to that event to be weaker.

We find support for most of our hypotheses in an event study of 94 spells of deadly violence that occurred under the two interim regimes that ruled Egypt during the Arab Spring. Our study thereby contributes to three streams of management research. First, it contributes to the behavioural perspective of investor decision-making, which has proposed that investors tend to infer the intentions of managers from signals (Connelly et al., 2011), given that these intentions may be self-serving and are unlikely to be made public (Schijven and Hitt, 2012). Our findings enrich this perspective by showing that investors also use signals to develop insight into the private intentions of external actors, in our case the political intentions of interim governments in former autocracies. In addition, our findings suggest that investors use firm-specific characteristics in the form of a firm's foreign footprint and ownership structure as signals of its resilience to adverse political developments, given that this resilience is generally also hard to ascertain otherwise (DesJardine et al., 2019).

Second, our study contributes to research on how firms are affected by violence. Specifically, whereas prior studies explored how firms are affected by the severity and spatial attributes of violence (Dai et al., 2013, 2017; Witte et al., 2017), our study focuses attention on the distribution of the fatalities across the parties involved and shows the relevance of this distribution for firms' market value.

Finally, our study contributes to management research on political uncertainty by focusing on a hitherto unexplored source of such uncertainty, namely the private nature of a regime's political intentions. Most prior management studies of political uncertainty conceptualized such uncertainty as originating from a lack of checks and balances in a country's political system (e.g., Hendriks et al., 2018; Henisz, 2000).

\section{BACKGROUND: INTERIM REGIMES AND THEIR INTENTIONS}

When an autocratic country experiences a coup, revolution, or foreign invasion that causes its regime to collapse, an interim government is typically installed to initiate a transition to a democratic new normal (Guttieri and Piombo, 2007). Such a government differs from a conventional government in at least two important ways. First, whereas a conventional government tends to develop and implement a wide variety of policies, an interim government usually has a very narrow mandate. In a former autocracy, an interim government's primary policy task is usually to organize free and fair elections that are meant to mark the beginning of a democratic new normal for the country and its populace (Seely, 2009). Second, interim governments are supposed to rule for a shorter period than their conventional counterparts. Specifically, they are expected to hand over power to a group of elected representatives within a reasonable timeframe, typically regarded to be two years (Shain and Linz, 1995).

Although interim regimes in former autocracies are supposed to organize democratic elections and hand over power to elected representatives soon afterwards, they may not necessarily intend to do so (Derpanopoulos et al., 2016; Pevehouse, 2005). At any time during their tenure, such regimes may privately intend to become their country's new autocratic rulers, as they may develop an obsession for political power and a taste for 
the psychological and monetary benefits it entails, including social status and personal wealth (Lewis, 1994; McGuire, 1995). Conversely, interim regimes may initially intend to become autocratic rulers but later start to become more committed to democratization under pressure of powerful foreign nations that may threaten to intervene in the country (BBC, 2005; Seely, 2009). Although such shifts in an interim regime's political intentions will ultimately materialize in the cancellation or the holding of national elections, these shifts are usually not observable to regime outsiders until then.

Because interim regimes' political intentions may experience shifts that are not directly observable, potential and actual investors in local firms face substantial uncertainty during interim periods about a country's political outlook. Consequently, they will find it challenging to determine whether to buy, hold, or sell equity stakes in these firms during such periods. To be able to make informed investment decisions in the presence of the political uncertainty they face, investors will likely want to have insight into an interim regime's political intentions over the course of its tenure. Below, we advance a framework explaining how they develop that insight. This framework combines a behavioural perspective on investor decision-making with insights from political science research on regimes' use of violence.

\section{THEORY AND HYPOTHESES}

\section{Information Asymmetries and Signals}

Information asymmetries, defined as situations wherein a party lacks information on another party's traits or intentions, constitute a cornerstone of management research on decision-making (Bergh et al., 2014). Such asymmetries may exist between various actors, of which those between investors and managers have received most research attention (Bergh et al., 2019). By virtue of their insider status and active engagement in corporate decision-making, managers generally possess superior information on their firms' traits and capabilities, and are thus entrusted by shareholders to take decisions that maximize the latter's wealth. Yet, the interests of managers and shareholders are not always aligned (Eisenhardt, 1989), meaning that managers may engage in behaviour that serves to attain their own objectives (Berle and Means, 1932). Because these objectives may be at odds with shareholder value creation, for example because they concern empire-building or personal pay maximization (Haleblian et al., 2009), investors are usually keen on discerning the true intentions of the top management of the firms they have invested or consider investing in (Schijven and Hitt, 2012).

Discerning these intentions is typically challenging for investors, however. Even though managers may make public statements that supposedly reflect their intentions, such statements cannot be taken at face value because they may be nothing more than 'cheap talk' meant to appease investors (Almazan et al., 2008) or distract attention from actual practice (Westphal and Zajac, 2001). Managers seeking to protect their position are prone to keep any opportunistic intentions they may have to themselves, meaning that corporate insiders such as directors and external experts such as financial analysts are also unlikely to be useful sources of information on managers' intentions (Bergh et al., 2019). 
Investors seeking to develop valuable insights into managers' intentions are thus typically left with little choice but to resort to signals, defined as 'crude but readily available pieces of public information that reflect an underlying, hard-to-verify reality' (Campbell et al., 2016, p. 166). The information to which a signal pertains is crude in two ways. First, the information is not necessarily completely accurate (Epstein and Schneider, 2008; Park and Patel, 2015), for example because it concerns an estimate or is based on hearsay. Second, even if the information is accurate, it is not always perfectly correlated with the unobserved construct it is supposed to capture (Busenitz et al., 2005; Connelly et al., 2011). Nonetheless, in the absence of more reliable insights, signals are useful cues that shed at least some light on matters that investors find hard to gauge otherwise (Caner et al., 2018; Schepker et al., 2018). Investors have for instance been shown to use managers' compensation structures, acquisition experience, and cultural backgrounds as signals of managers' motives for making acquisitions (Haleblian et al., 2009; Schijven and Hitt, 2012).

Besides relying on signals to develop insight into the intentions of managers, investors will likely also rely on signals to develop insight into the political intentions of interim regimes in former autocracies. The reason is that, like the intentions of managers, the political intentions of interim regimes are hard to uncover otherwise. Although interim officials may make statements in which they claim to be committed to holding elections and relinquishing power afterwards, these statements may merely be symbolic, aimed at avoiding short-term civil unrest (Shain and Linz, 1995). Furthermore, developing insight into interim officials' political intentions by creating personal ties with them is a risky endeavour in former autocracies, because such ties can turn into major liabilities if the interim regime is replaced by a regime with a different political or ideological stance (Darendeli and Hill, 2016; Siegel, 2007). As interim governments with the intention to become autocratic rulers are likely to keep that intention to themselves in fear of civil unrest, political analysts are unlikely to have private insight into that intention either.

Given that signals are likely to be the only form of information for investors to develop insight into an interim regime's political intentions, what signal will they rely on? Below we propose that investors will focus on the relative number of civilian fatalities during events of government-related violence within the country.

\section{Interim-Regime Dominance as a Signal of Political Intentions}

Defined as 'violence against and by the government' (van de Vliert et al., 1999, p. 291), government-related violence concerns physical confrontations within a country between civilians and governmental actors, whereby each of these groups can be either the perpetrator or the victim. In former autocracies with an interim regime, such confrontations may include anti-regime demonstrations that result in clashes with state security forces, street skirmishes between civilians and policemen, terrorist attacks on public properties such as army checkpoints, and military or police raids on terrorist strongholds or residences of political activists (Acemoglu et al., 2013; Oetzel and Oh, 2014; Witte et al., 2017). The frequent involvement of weaponry in such violence often leads to fatalities among civilians and governmental actors (Oetzel and Getz, 2012). 
For investors, the share of civilian fatalities in the total number of fatalities of government-related violence may serve as a signal of an interim regime's political intentions. As explained in more detail below, this is because these intentions are likely to translate into the amount of force that a regime uses against civilians and, thereby, into the distribution of fatalities among civilians and state actors.

A sizeable body of political science research has shown that regimes that intend to impose their rule on their people tend to use greater force in various types of violent confrontations with civilians than regimes that aim to be responsive to civilian demands and interests (Davenport, 1999, 2007; Imbusch, 2003; Stanton, 2016; Straus, 2012). Scholars have provided two reasons why that is the case. First, the use of strong force against civilians is instrumental to realizing a regime's intention to strengthen its rule because the use of such force is a way to eliminate or intimidate political opponents (Davenport, 2007). Second, regimes that intend to impose their rule on their people are likely to lack a moral compass and thus see little merit in respecting human rights by exercising restraint in violent confrontations with civilians (Rummel, 1997).

A regime that uses strong force against civilians tends to deploy vast military and police resources throughout its territory (Bellin, 2004; Ukiwo, 2009), leading it to inflict many civilian fatalities and suffer limited losses among its own actors during instances of government-related violence. In other words, the use of strong force against civilians is likely to result in a high share of civilian fatalities in the total number of fatalities of government-related violence (Levy, 2010). For the sake of brevity, we refer to this civilian fatality share as the 'dominance' displayed by an interim regime.

An interim regime's dominance in government-related violence is a crude piece of public information and thus qualifies as a signal. It constitutes public information because media reports tend to specify the number of fatalities of instances of violence and the distribution of this number across civilian and state actors. Moreover, it is a crude piece of information in two ways. First, the reported distribution of fatalities is not necessarily completely accurate because it may be an estimate or based on hearsay. Second, the fatality distribution reported for a given instance of violence is not a perfect indicator of an interim regime's political intentions, since this distribution also depends on other factors, including civilians' conflict experience and the types of weapons they had at their disposal.

As explained in the Background section, an interim regime's political intentions can change during its tenure. Since these intentions tend to be reflected in the dominance displayed by the regime during government-related violence, this dominance may thus vary across episodes of such violence. The following case supports the existence of such longitudinal co-variation between a regime's political intentions and its displayed dominance. During the First Intifada in 1987, the Israeli regime had the intention to contain the Palestinian street-uprising and therefore implemented 'a policy of relatively restrained use of force' (Levy, 2010, p. 393) that included the use of rubber bullets instead of live ammunition and the investigation of every incident resulting in a Palestinian fatality. In contrast, during the 2009 Gaza offensive, the Israeli government had the intention to neutralize the Palestinian militant organization Hamas after the latter had launched a wave of rocket attacks against southern Israel. This intention led the Israeli regime to use 'overwhelming power' in the form of massive air and ground attacks, and to violate 
human rights by treating all Palestinians out on the street as enemies of the state and thus as legitimate military targets (Levy, 2010, p. 400).

The different intention of the Israeli regime across both episodes of violence was, in turn, clearly reflected in the distribution of fatalities among both sides. Whereas during the First Intifada the Palestinian fatality count was six times higher than the number of Israeli state fatalities, during the Gaza offensive it was 86 times higher (Levy, 2010). Although this example pertains to a conventional government rather than an interim one, it does show that the dominance displayed by a regime may vary substantially over time as a result of changes in the regime's political intentions.

In the case of an interim regime in a former autocracy, investors aim to gain insight into whether the regime at a given point in time has the intention to initiate a democratic new normal or to become the new autocratic ruler. When an interim regime has the latter intention, it aims to impose its will on its people by illegitimately expanding its mandate. Since regimes that aim to impose their will on their people have been shown to use strong force against them (e.g., Davenport, 1999, 2007), and since the use of such strong force expresses itself in high regime dominance, an interim regime with autocratic intentions at a given point in time will likely display high dominance during violence occurring at that time. By contrast, when an interim regime at a given point in time has the intention to initiate a democratic new normal, it will likely display restraint during violence occurring at that time, so as to convincingly distance itself from the oppressive practices of its autocratic predecessor and encourage civilians to freely participate in the country's elections as either candidates or voters. We therefore expect investors to interpret higher interim-regime dominance during a given event of government-related violence as a signal that the regime has weaker democratic intentions at that time.

In turn, investors will likely associate weaker democratic intentions on the part of an interim regime with a less favourable political outlook for locally listed firms. The reason is that a weaker democratization intention among interim officials suggests a higher possibility that these officials will recreate an autocratic system, which usually constitutes a less desirable state of affairs for firms than a democratic system (Jensen, 2008). In autocracies, firms are more likely to encounter rent-seeking government officials and tend to experience greater difficulties in anticipating policy changes due to the generally less transparent political decision-making processes in such countries (Treisman, 2007; Youngs, 2004). Autocracies are usually also characterized by lower levels of human capital formation, infrastructure spending, and public service provision (Brown and Hunter, 2004; Lake and Baum, 2001) and therefore tend to experience lower economic growth than democracies (Doucouliagos and Ulubaşoğlu, 2008).

Furthermore, when interim officials indeed start to recreate an autocratic system, they may trigger a public backlash that causes further government-related violence or even a civil war (Derpanopoulos et al., 2016; Pevehouse, 2005). Such continued violence is likely to suppress local demand (Hiatt and Sine, 2014) and disrupt the local supply of production factors such as labour, capital, and raw materials (Darendeli and Hill, 2016), thereby harming locally-listed firms.

Since investors will likely interpret higher interim-regime dominance during a given violent event as a signal that the regime has weaker democratic intentions at that time, 
and since they will likely associate such intentions with a less favourable political outlook for locally listed firms, we propose:

Hypothesis 1: Investors react more negatively to violent events characterized by higher interim-regime dominance.

\section{The Moderating Role of Firm-Specific Signals}

Although investors will likely react more negatively to violent events characterized by higher interim-regime dominance, the degree to which they do so will vary across firms. This is because investors will likely consider some firms to be more resilient to the above-described adverse political developments that may result from high interimregime dominance.

According to the literature on organizational resilience to political turmoil (Dai et al, 2017; Darendeli and Hill, 2016; Oh and Oetzel, 2017), some firms have a pre-existing capacity, deriving from organizational resources and structures, that helps them cope with and survive adverse political developments by cushioning the harmful impact of such developments (De Carolis et al., 2009). Organizational resilience is a complex property that is difficult to observe directly, however (DesJardine et al., 2019). Consequently, investors will likely look for firm-specific signals that serve as proxies for a firm's resilience to adverse political developments. Below we argue that they will rely on three such signals: a firm's foreign footprint, its indebtedness, and its ownership structure.

\section{Foreign Footprint}

While some firms realize most or all of their sales domestically, others realize a high share of their sales abroad and thus can be said to have a large foreign footprint (Hendriks et al., 2018). Investors will likely perceive a larger foreign footprint as a signal that a firm is more resilient to the adverse political developments that may result from high interim-regime dominance. The reason is twofold. First, all else equal, firms with a larger foreign footprint realize a smaller portion of their sales domestically and will thus experience a relatively smaller decline in profitability when adverse political developments cause domestic demand to drop (Kim et al., 1993). Second, firms with a larger foreign footprint tend to have better switching options for their domestic activities (Kogut and Kulatilaka, 1994). Specifically, they are more likely to have tangible and intangible assets abroad, including sales offices, distribution and client networks, and possibly production plants. Consequently, they are usually better positioned to shift domestic sales or production activities abroad in response to adverse domestic developments, causing their total sales to suffer less from such developments (Lee and Makhija, 2009). Overall, these arguments are consistent with the more general view that geographic diversification provides a hedge against country-specific risks such as political upheaval, especially when such risks do not correlate highly across markets (Dai et al., 2017; Witte et al., 2017). Accordingly, we hypothesize:

Hypothesis 2a: A firm's foreign footprint weakens the degree to which investors react more negatively to violent events characterized by higher interim-regime dominance. 


\section{Indebtedness}

A firm's indebtedness refers to its amount of debt relative to its equity capital (Schijven and Hitt, 2012). Investors will likely perceive higher indebtedness as a signal that a firm is less resilient to the adverse political developments that high interim-regime dominance may entail. This is because more indebted firms tend to have less financial slack and are therefore more likely to go bankrupt when adverse political developments disrupt the local economy (Bourgeois, 1981; Cheng and Kesner, 1997). Specifically, because more indebted firms usually need to pay more interest, they are generally less profitable and therefore tend to face greater difficulties in sustaining their interest payments when their revenues decrease as a result of adverse political developments (Kochhar and Hitt, 1998). Furthermore, because owners of capital are usually less willing to provide funds to more indebted firms (George, 2005), such firms are less well able to raise additional capital that they may need to restructure their operations in response to political and economic adversity (Bromiley, 1991; Su et al., 2009). For these reasons, we hypothesize:

Hypothesis 2b: A firm's indebtedness strengthens the degree to which investors react more negatively to violent events characterized by higher interim-regime dominance.

\section{Ownership Concentration}

A firm's ownership structure, finally, concerns the degree to which its equity is concentrated in the hands of one or a few large shareholders ('blockholders') or dispersed across many highly liquid or diversified owners. Compared to the latter, blockholders typically have longer-term investment horizons and a lower tendency to exit the firm because of the illiquid nature and large size of their investment (Edmans and Holderness, 2017; Shleifer and Vishny, 1997). For similar reasons, blockholders also tend to be more dedicated towards the companies they invest in, oftentimes using private resources to 'prop-up' their firms during stretches of poor performance (Friedman et al., 2003). Finally, blockholders typically possess effective control over their firms' investment, contracting, and financing policies, meaning that they have considerable discretion over the strategic choices of their firms (Stulz, 2005).

Building on research on the value of corporate ownership structures during times of adversity (e.g., Ma et al., 2014; Mangena et al., 2012), we argue that investors will likely perceive more concentrated ownership as a signal that a firm is more resilient to the adverse political developments that may result from high interim-regime dominance. The reason is threefold. First, given the generally illiquid nature of their holdings, blockholders are less likely to sell their shares when adverse political developments occur (Hill and Snell, 1989), opting instead to just 'sit out' these developments and the capital losses associated with them. Consequently, firms with a concentrated ownership structure are more likely to be able to delay radical and costly restructurings until features of the ultimate policy environment become more concrete (Kozikhode, 2016; Rivoli and Salorio, 1996). In enabling the option of a wait-and-see approach, concentrated ownership provides strategic flexibility in the face of what could turn out to be a temporary deterioration of the political and economic environment. Second, as the possession of large 
block holdings is often suggestive of wealth (Carney and Gedajlovic, 2001; Heugens et al., 2009), blockholders may be able to infuse the firm with private funds when the political and economic environment deteriorates (Bae et al., 2012). Finally, the concentration of control and decision rights has been shown to allow firms to operate with lower transparency (Fan and Wong, 2002). Although this feature of concentrated ownership has conventionally been argued to result in greater information asymmetries between exploitative firm insiders and minority investors, Morck (1996, p. 73) contends that closely-held firms are also more naturally perceived as 'discrete and reliable partners' for politicians of all strides who seek to trade favours with business actors. For investors, concentrated ownership can thus indicate that a firm is politically-versatile - that is, capable of engaging with and successfully courting whichever regime ultimately secures power (Chen et al., 2011; Morck et al., 2005). For these reasons, we hypothesize:

Hypothesis 2c: Concentration of a firm's ownership weakens the degree to which investors react more negatively to violent events characterized by higher interim-regime dominance.

\section{DATA AND METHODS}

\section{Empirical Gontext: Government-Related Violence in Egypt During the Arab Spring}

To test our hypotheses, we collected data on instances of government-related deadly violence in Egypt following the overthrow of President Hosni Mubarak's autocratic regime. The ouster of his regime, and the events that transpired afterwards, were part of the broader wave of uprisings against authoritarian governments that swept the Middle East and North Africa in early 2011, and which collectively became known as the 'Arab Spring'.

The Arab Spring was instigated in late 2010 by the self-immolation of a Tunisian street vendor after he was harassed by the police. Soon afterwards, a fervent revolutionary movement spread, first in Tunisia itself and later to other Arab states, including Egypt, Libya, Syria, Yemen, and Bahrain. Underlying this movement was massive popular dissatisfaction with the autocratic status quo that characterized these countries, and which had manifested itself in the form of police brutality, rampant corruption, and the suppression of political freedom. For the first time in decades, the once-stable autocracies of the Middle East and North Africa seemed vulnerable, and the rise of a democratic new normal in the region was no longer deemed unlikely (Lynch, 2012).

In Egypt, mass demonstrations against Mubarak's 30-year autocratic rule began on 25 January 2011 and continued until he was forced to resign on 11 February 2011. Immediately afterwards, the army-affiliated Supreme Council of Armed Forces (SCAF) took temporary control of the country for what was supposed to be six months, after which elections would be held. Elections were postponed, however, and the SCAF extended its rule by an additional ten months. 
Elections were ultimately held in May 2012 and Mohamed Morsi of the previously outlawed Muslim Brotherhood became Egypt's first democratically elected President on 30 June 2012. Although Morsi's election was internationally heralded at the time as a 'milestone' in establishing a democratic new normal in the country (Reuters, 2012), his tenure was soon marred by allegations of economic incompetence, authoritarianism, and adherence to a strict religious ideology that was incompatible with democracy, culminating in large-scale demonstrations against his rule. In a move described by US Secretary of State John Kerry as a step towards 'restoring democracy', the army ousted Morsi on 3 July 2013 and instated a second interim regime led by the Head of the Supreme Court, Adly Mansour. This regime organized a new round of elections, which were won by Abdel Fatah el-Sisi, the former Minister of Defense under Morsi and leader of the coup against him. El-Sisi was sworn into office as President on 8 June 2014.

Our study covers both interim regimes, spanning the period from 23 March 2011 to 29 June 2012 and that from 4 July 2013 to 7 June 2014. ${ }^{1}$ There are two reasons why this two-part interim period is suitable for exploring how investors react to interimregime dominance during events of government-related violence. First, as shown below, the period contained many such events that were characterized by varying degrees of interim-regime dominance. Second, investors are likely to have used this dominance as a signal of the political intentions of the two interim regimes since there was considerable uncertainty as to whether these regimes would actually initiate a transition to a democratic new normal. Specifically, although both regimes repeatedly made public statements in which they claimed to be committed to holding elections and relinquishing power to elected authorities soon afterwards (Reuters, 2014), they also engaged in behaviour that could be seen as being at odds with a genuine desire for democratization (The Guardian, 2012; The New York Times, 2011). For instance, under the SCAF, protestors were often punished by military tribunals and parliament was dissolved. Similarly, under President Mansour, the Muslim Brotherhood -the largest opposition group in the country- was officially classified as a terrorist organization.

\section{Data Collection and Empirical Approach}

To determine investors' reactions to the dominance displayed by the two interim regimes during the violence occurring throughout their tenure, we conducted an event study. The methodology underlying such a study assumes that exogenous, unanticipated events, such as reports of government-related violence, reveal new information to investors, who assess the expected consequences of this information for firms' future cash flows and decide whether to buy, hold, or sell firms' shares based on these expected consequences (e.g., Abadie and Gardeazabal, 2003; Guidolin and La Ferrara, 2007). The new information revealed by an event is thus swiftly incorporated into a firm's stock price (McWilliams and Siegel, 1997). Although investors may expect instances of government-related violence to occur during interim periods in former autocracies, they are unlikely to be able to predict the specificities of these instances (Czinkota et al., 2010; Oetzel and Oh, 2014), including the dominance shown by the interim regime at a given point in time. We thus contend that this dominance reveals new information to investors that causes them to update their expectations about the regime's political intentions. 
To identify the most notable instances of government-related violence during the Egyptian interim period, we collected all 4,891 front-page articles published during that period in Egypt's most widely-read independent daily newspaper, Al-Masry Al-Youm (AMAY). We chose this newspaper because its independence likely implies that investors consider its articles more reliable than those published in state-owned newspapers (Blaydes, 2006), and because its high readership base is likely to encompass the bulk of Egyptian investors, who accounted for 77 per cent of all trading on the Egyptian stock exchange over 2011-14 (The Egyptian Exchange, 2014). We then instructed an Arabicspeaking research assistant to carefully read all articles and identify those that reported instances of government-related violence in Egypt that had resulted in at least one fatality among either civilians or state actors. The assistant identified 128 such articles, corresponding to 2.6 per cent of the total number of front-page articles. ${ }^{2}$ To assess the reliability of the coding, one of the authors of this study independently coded a random selection of 423 articles, generating a 97.2 per cent inter-rater agreement rate.

When analysing the dates on which the instances of government-related deadly violence were reported, we noticed that these dates were sometimes clustered, particularly around special occasions such as the anniversary of Mubarak's overthrow and new appointments within the interim cabinet. Moreover, prior research has shown that government-related violence may be reciprocal (Francisco, 1996; Lichbach and Gurr, 1981), meaning that the perpetrators of a violent act may become the targets of a violent counteract the next day. These observations led us to combine all consecutive days of reported government-related violence into distinct 'spells', which form the events in our study (see Acemoglu, et al., 2017). A spell begins when an article reports an instance of government-related deadly violence and continues as long as at least one other instance of such violence is reported every next day. A day without reported government-related deadly violence thus serves as the natural cut-off point of a spell. The 128 identified instances of violence were thus reduced into 94 spells. The average and maximum number of instances of violence per spell was 1.4 and 5 respectively, while the average number of days between consecutive spells was 8 . The average number of fatalities per spell was 13 .

\section{Dependent Variable}

To quantify investors' reactions to the dominance displayed by the interim regime during each spell of violence, we first obtained from Datastream longitudinal data on the daily stock prices of 125 firms listed on the Egyptian stock exchange. We then employed the following standard market model to estimate the firm-specific relationship between these stock prices and a stock market-wide benchmark index for an estimation period prior to each spell of violence:

$$
A R_{i, t}=R_{i, t}-\left(\hat{a}_{i}+\hat{b}_{i} \cdot R_{m, t}\right)
$$

where $\hat{a}_{i}$ and $\hat{b}_{i}$ are the estimates for firm $i$ of the OLS regression $R_{i, t}=a_{i}+b_{i} \cdot R_{m, t}+e_{i, t}$; $R_{i, t}$ is the return on firm $i$ 's stock on day $t$ of the estimation period; $R_{m, t}$ is the return of the benchmark index on day $t$ of that period; $a_{i}$ the intercept and $b_{i}$ the slope coefficient for firm $i$; and $e_{i, t}$ the random disturbance estimate of the market model. ${ }^{3}$ 
Because the stock prices of the focal firms perfectly predict the performance of an Egyptian benchmark index, we used as our benchmark index the MSCI Emerging Market Index, which includes 23 other national stock market indices besides the Egyptian one. In line with prior studies (e.g., El Nayal et al., 2019), we chose an estimation period starting 285 days and ending 30 days before the start date of the event window of a given spell of violence. ${ }^{4}$ The start date of each event window was defined to be the day prior to the reporting on the first instance of violence within the spell. We did so because newspapers typically report instances of violence the day after their occurrence, whereas investors may already hear about them on the day they occur (via social media, for example). ${ }^{5}$ The end date of each event window was defined to be the final consecutive day of reported violence within the spell. Thus, the event window of a spell consisting of three instances of government-related violence reported in AMAY on 16, 17, and 18 March 2014, respectively, was defined to be four days, i.e., 15 March through 18 March. By contrast, the event window of an isolated instance of such violence reported in AMAY on 10 October 2011 was defined to be the two-day period of 9 October and 10. The Cumulative Abnormal Returns (CARs) generated by each spell were calculated as the sum of the daily abnormal returns realized during the spell's event window.

\section{Main Independent Variable}

We measured the interim regime's dominance during a given spell of violence by the share of civilian fatalities in the total death toll of the spell. We derived this share from the fatality figures that AMAY reported in its articles on the instances of violence occurring within the spell. Specifically, we calculated the total number of civilian fatalities across all instances of violence within the spell as well as the total number of governmental fatalities across these instances. We then divided the former number by the sum of the two numbers. In the few cases where an article reported either a fatality range or conflicting figures obtained from different sources, we used the mean value. The share of civilian fatalities in the total death toll of a spell ranges from 0 to 1, with higher values indicating higher interim-regime dominance. Several prior studies of government-related violence used a comparable yet slightly different measure, namely the ratio of civilian fatalities to government fatalities (Kaldor, 2013; Levy, 2010; Richani, 2016). The disadvantage of that ratio is that it has no value for spells of violence without government fatalities. To avoid having to exclude such spells and thereby potentially introduce sample selection bias, we used the share of civilian fatalities in the total death toll instead.

\section{Moderating Variables}

We measured a firm's foreign footprint at the time of a given spell of violence by the share of the firm's foreign sales in its total sales in the last completed fiscal year prior to the spell (Hendriks et al., 2018). Firms with a higher such share realize a larger portion of their sales outside Egypt and thus have a larger foreign footprint. A firm's indebtedness at the time of a given spell of violence was measured by the book value of its total debt relative to that of its common equity in the last completed fiscal year prior to the spell (Schijven and Hitt, 2012). Concentration of a firm's ownership at the time of a spell was measured by the percentage of the firm's shares that was held by its five largest 
shareholders in the last completed fiscal year prior to the spell (Hu and Izumida, 2008). The higher this percentage, the more concentrated a firm's ownership. The data on these three moderating variables were obtained from Datastream and Thomson Eikon. ${ }^{6}$

\section{Control Variables}

We controlled for several spell-level and firm-level factors that may also affect investor reactions to spells of government-related violence. We first of all controlled for the severity of a spell of violence by entering (i) its total death toll and (ii) its length in days. Regardless of the distribution of the fatalities across civilians and government actors, local stock markets tend to react more negatively to violence resulting in more fatalities (Eldor and Melnick, 2004), presumably because such violence is generally more disruptive for local firms. ${ }^{7}$ For similar reasons investors may also react more negatively to longer spells of violence.

We also controlled for several spatial attributes of the spells, since spatial aspects of violence have been shown to influence firms' vulnerability to it (Dai et al., 2013). Specifically, we controlled for the spatial concentration of violence within a spell by entering a dummy variable equal to 1 if all instances of violence in the spell occurred in the same city, and 0 otherwise. We also included a dummy variable coded 1 for spells that contained one or more instances of violence in Cairo, since violence in a country's economic and political centre may be more disruptive. Likewise, we included a dummy variable coded 1 for spells that contained instances of violence in the Sinai region, since this region became a hotbed for extremists after Mubarak's fall and therefore a frequent target of military operations, which may have been characterized by relatively high levels of interim-regime dominance. The data on these spatial characteristics of the spells were obtained from the newspaper articles.

We also entered a dummy variable coded 1 for spells starting on a Friday, since most mass protests during the interim period took place on that day (Acemoglu et al., 2017), and since such protests often resulted in severe violence lasting several days. Furthermore, we entered a dummy variable coded 1 for spells of violence that occurred during the Islamic holy month of Ramadan. We did so because such spells may be less severe, given that Islam - Egypt's dominant religion - strongly denounces the use of violence during Ramadan. Likewise, we entered a dummy variable coded 1 for spells of violence that occurred under the second Egyptian interim regime and 0 for those that occurred under the first, so as to account for potential differences across these two categories of spells. Finally, we controlled for the number of days between the start of the focal interim regime's rule and the start of the focal spell, as violence occurring in the immediate aftermath of regime change may be more severe.

At the firm level, we controlled for a firm's size by entering the natural logarithm of the book value of the firm's assets and for its accounting performance by entering its return on equity. We also entered a firm's market-to-book ratio, measured by the market value of the firm's shares relative to the book value of its common equity. Furthermore, we entered a dummy variable coded 1 for firms headquartered in a city where violence took place during a given spell (see Dai et al., 2013). We also entered three variables measuring the percentage of the five largest shareholdings in the firm that were in the hands of 
(i) government agencies, (ii) non-Egyptian individuals or organizations, and (iii) financial institutions, respectively (Boyd and Solarino, 2016; Faccio and Lang, 2002). We entered these variables because not all types of large owners may be equally willing to maintain their shareholdings during times of adversity (van Essen et al., 2013), potentially causing investor reactions to spells of violence to differ across firms with different types of large owners. Finally, we controlled for a firm's industry by entering a set of dummy variables based on the two-digit SIC code of a firm's primary industry. The data on all firm-level variables were obtained from Datastream and Thomson Eikon, and pertain to the fiscal year preceding the focal spell of violence.

\section{Statistical Methods}

We managed to collect complete data on all variables for a sample of 6,908 firm-spell observations. We subsequently analysed this sample using the following Ordinary Least Squares regression equation:

$$
C A R_{i, j}=\alpha+\beta_{1} I R D_{j}+\beta_{2} I R D_{j} * M_{i}+\beta_{3} X_{j}+\beta_{4} Y_{i}+e_{i, j}
$$

where $C A R_{i, j}$ is the cumulative abnormal return on firm $i$ 's stock resulting from spell $j$, $I R D_{j}$ the interim regime's dominance during spell $j, M_{i}$ a vector of firm-level moderating variables, $X_{j}$ a vector of spell-level control variables, $Y_{i}$ a vector of firm-level control variables, and $e_{i, j}$ the error term.

Because the observed CARs on a firm's stock may be correlated across spells, we clustered the standard errors of the regression coefficients by firm (Cameron et al., 2011). To avoid multicollinearity stemming from the inclusion of the interactions between interim-regime dominance and the three firm-level moderating variables, we standardized all continuous predictors (Dawson, 2014).

\section{RESULTS}

Table I displays the descriptive statistics and pairwise correlations of our variables. It shows, among others, that the average CAR generated by a spell of government-related deadly violence is -0.17 per cent $(p<0.001)$. For comparison, Drakos $(2010)$ found that the average CAR resulting from 10,282 terrorist attacks in 22 countries over the period 1994-2004 was -0.05 per cent. The table also shows that, with the exception of the correlation between the dummy variable for spells of violence covering Cairo and the dummy variable for spells covering a firm's headquarters city $(r=0.707)$, all other correlations are below 0.5 , suggesting that multicollinearity is not a concern. This was confirmed by an inspection of the variation inflation factors (VIFs) of the independent variables, which were below the well-accepted multicollinearity threshold of 10 in all our regression models (Meyers et al., 2006), with the highest VIF being 4.87 .

Table II shows the results of the multivariate regression models that we estimated. Model 1 only contains the control variables, to which we add each of our variables of interest in the subsequent models. Model 2 tests Hypothesis 1, which proposed that investors react more negatively to violent events characterized by higher interim-regime dominance. This hypothesis is supported, since the regression coefficient of interim-regime 
O. El Nayal et al.

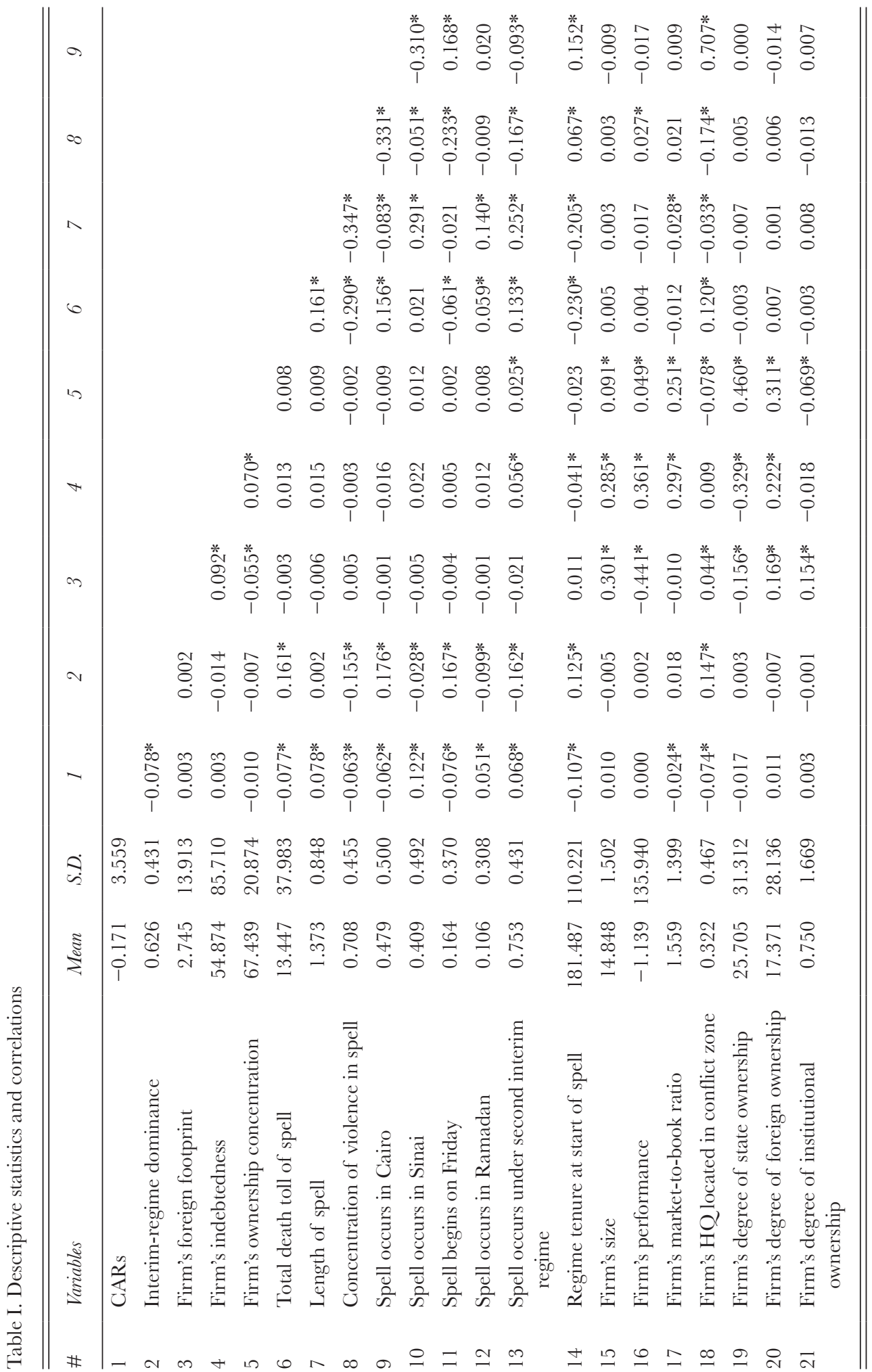


Towards a Democratic New Normal?

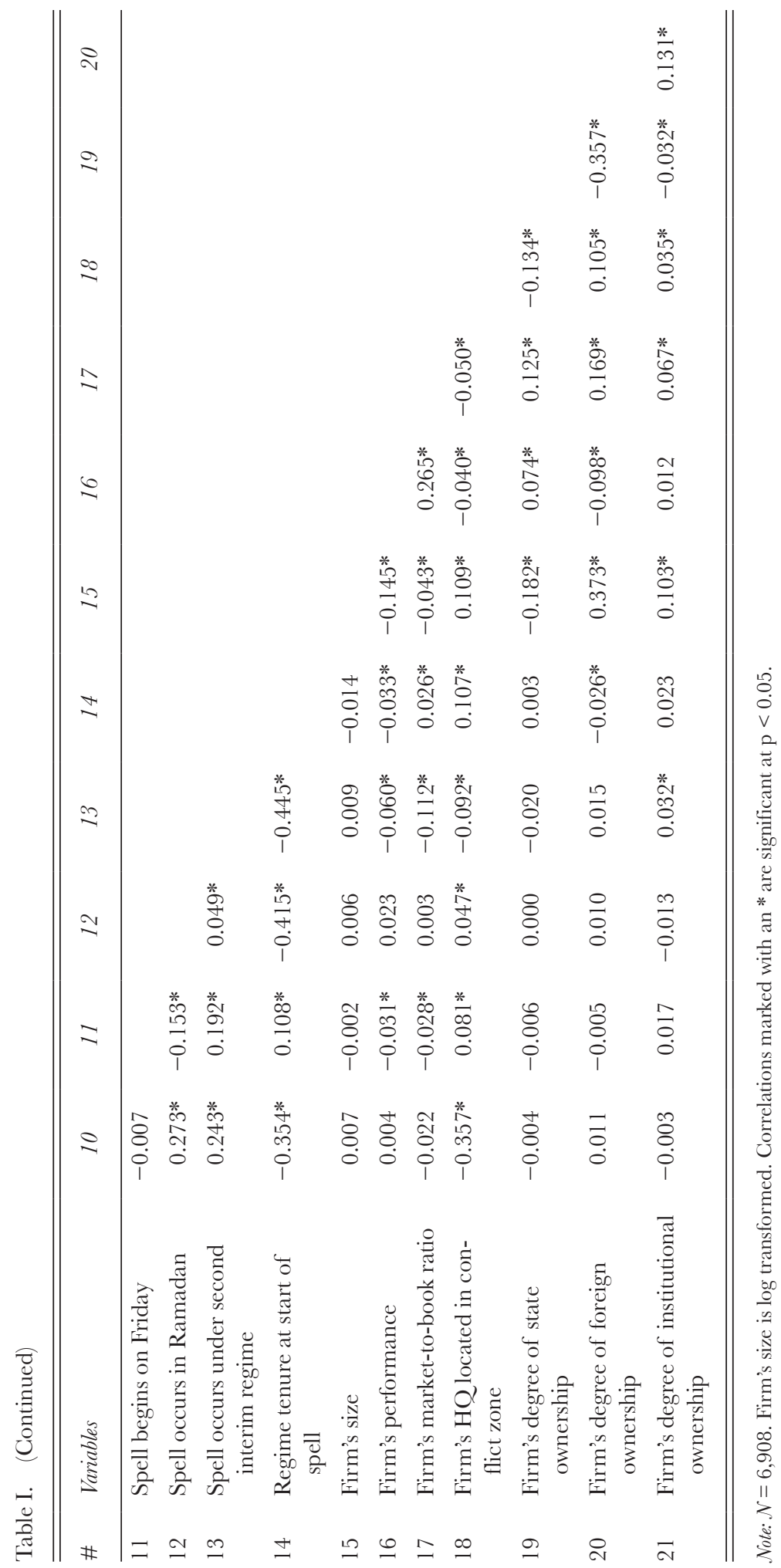

(C) 2020 Society for the Advancement of Management Studies and John Wiley \& Sons, Ltd. 


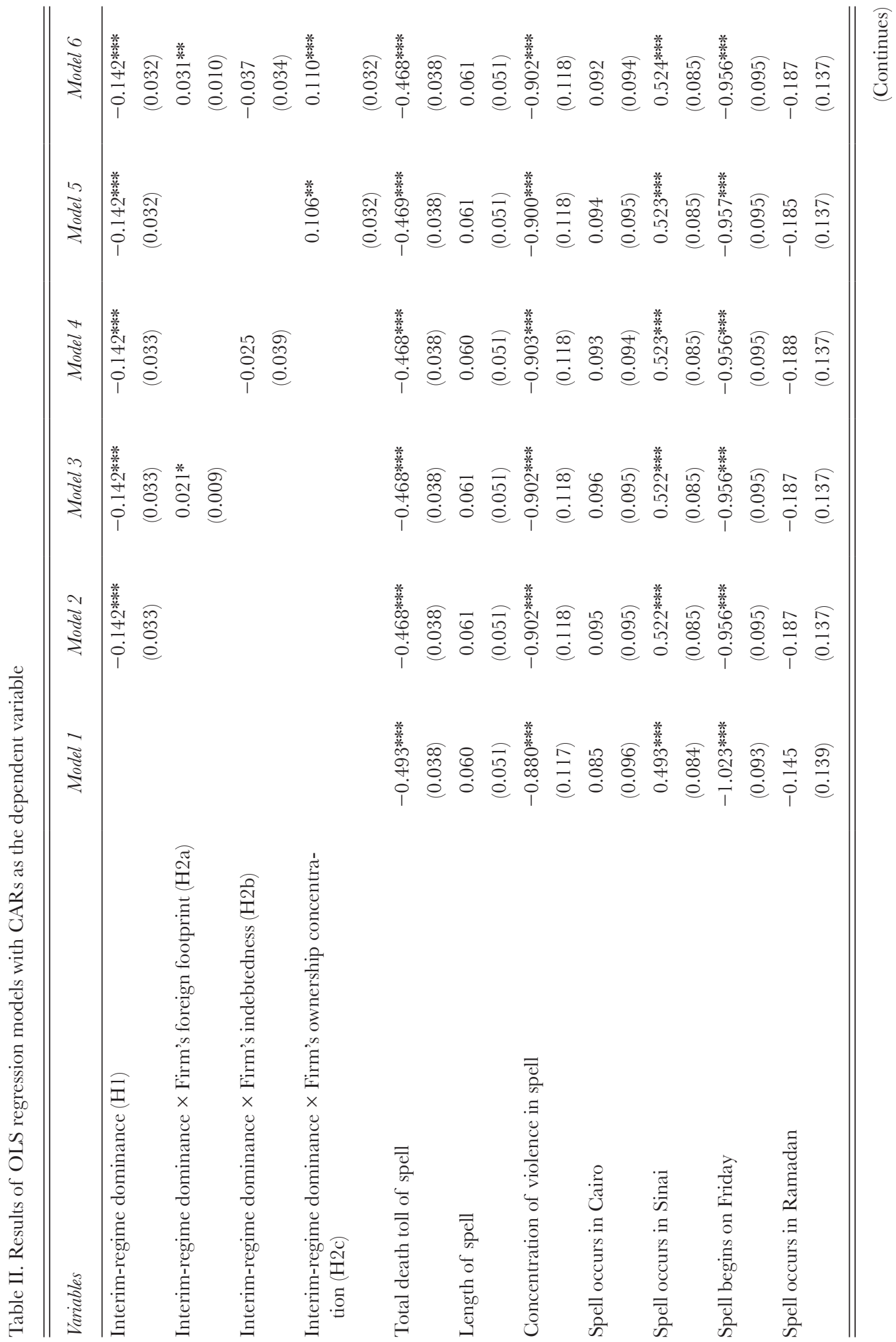




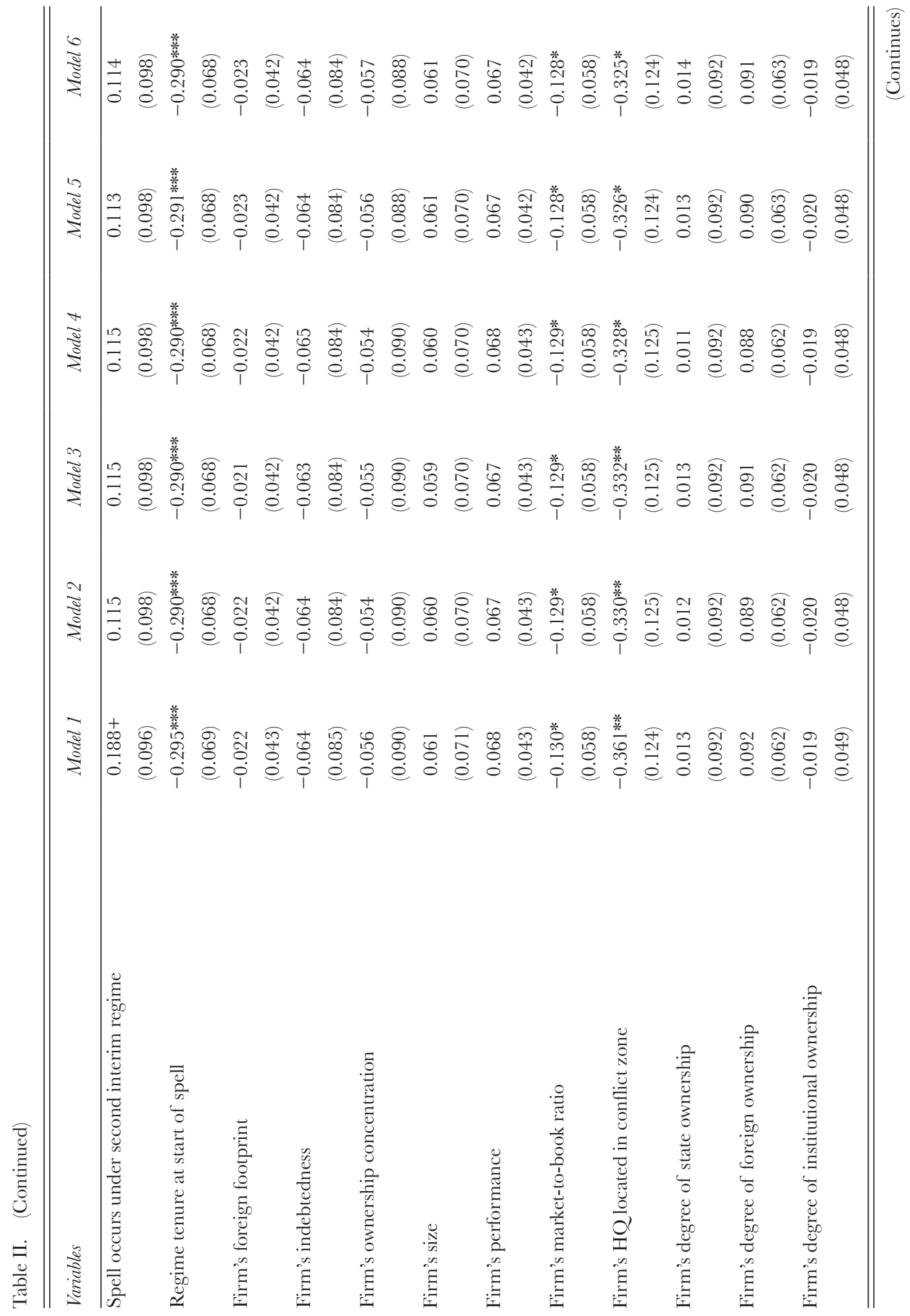




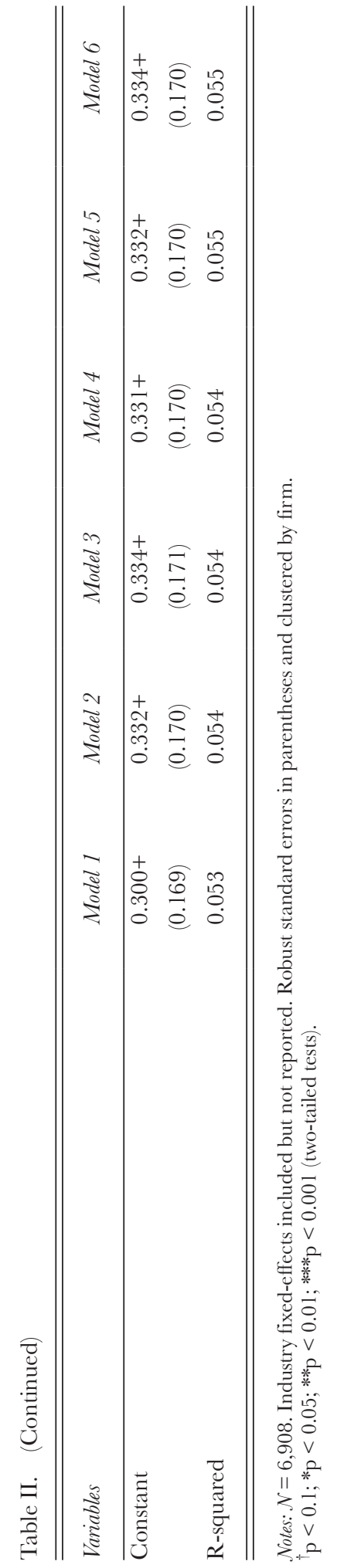

(C) 2020 Society for the Advancement of Management Studies and John Wiley \& Sons, Ltd. 
dominance is significantly negative in Model $2(\beta=-0.142, \mathrm{p}<0.001)$. The size of the coefficient indicates that an increase in interim-regime dominance from one standard deviation below to one standard deviation above the mean causes the CAR generated by a spell of violence to decrease by 0.28 per cent on average.

Hypothesis 2a stated that a firm's foreign footprint weakens the degree to which investors react more negatively to violent events characterized by higher interim-regime dominance. This hypothesis is tested in Models 3 and 6, both of which yield a significantly positive coefficient of the interaction between interim-regime dominance and a firm's foreign footprint $(\beta=0.021, \mathrm{p}<0.05$ and $\beta=0.031, \mathrm{p}<0.01$ respectively), lending support to Hypothesis 2a. To gain more insight into the interaction effect, we used the results of Model 6 to plot the relationship between interim-regime dominance and CARs at low and high values of a firm's foreign footprint, i.e., at values one standard deviation below and above the sample mean, respectively. As shown in Figure 1, interim-regime dominance has a negative effect on CARs among firms with small foreign footprints and among those with large ones, but this effect is weaker among the latter firms.

Hypothesis 2b, which predicted that a firm's indebtedness strengthens the degree to which investors react more negatively to violent events characterized by higher interim-regime dominance, is tested in Models 4 and 6. This hypothesis is not supported, as the coefficient of the interaction between interim-regime dominance and a firm's indebtedness is insignificant in both models.

Hypothesis 2c, finally, predicted that concentration of a firm's ownership weakens the degree to which investors react more negatively to violent events characterized by higher interim-regime dominance. This hypothesis receives support, as the interaction between interim-regime dominance and ownership concentration is significantly positive

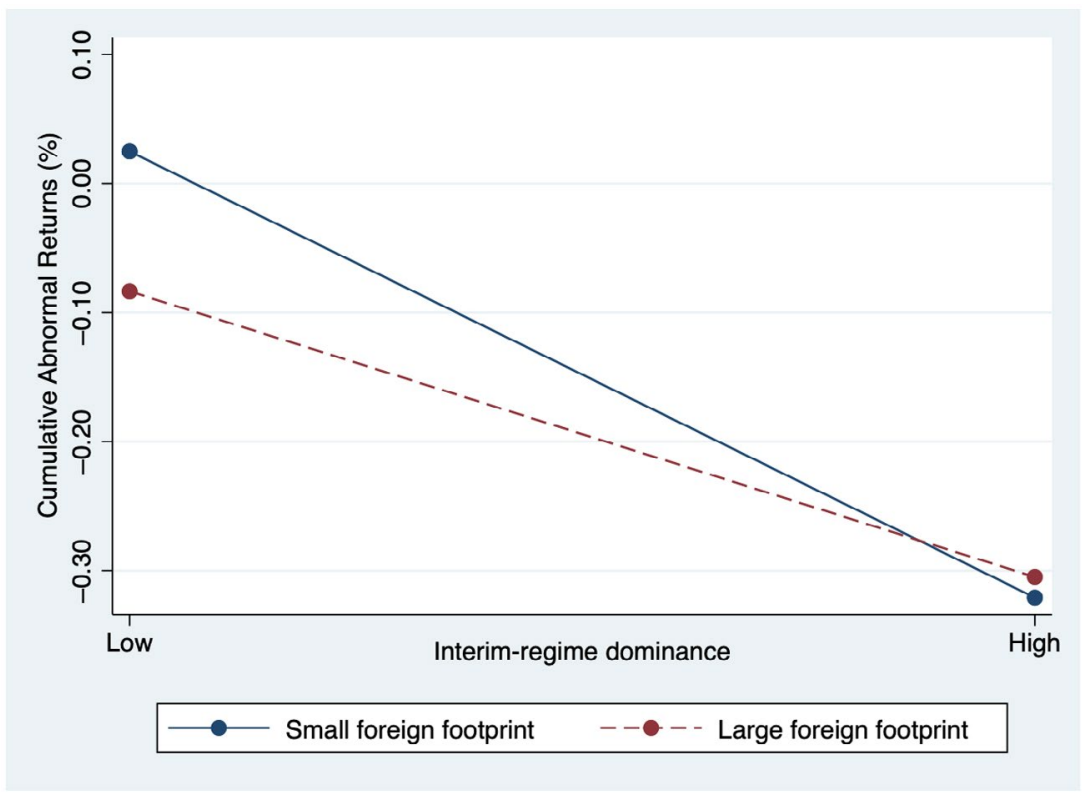

Figure 1. The effect of interim-regime dominance on CARs for firms with a small and large foreign footprint, respectively. 


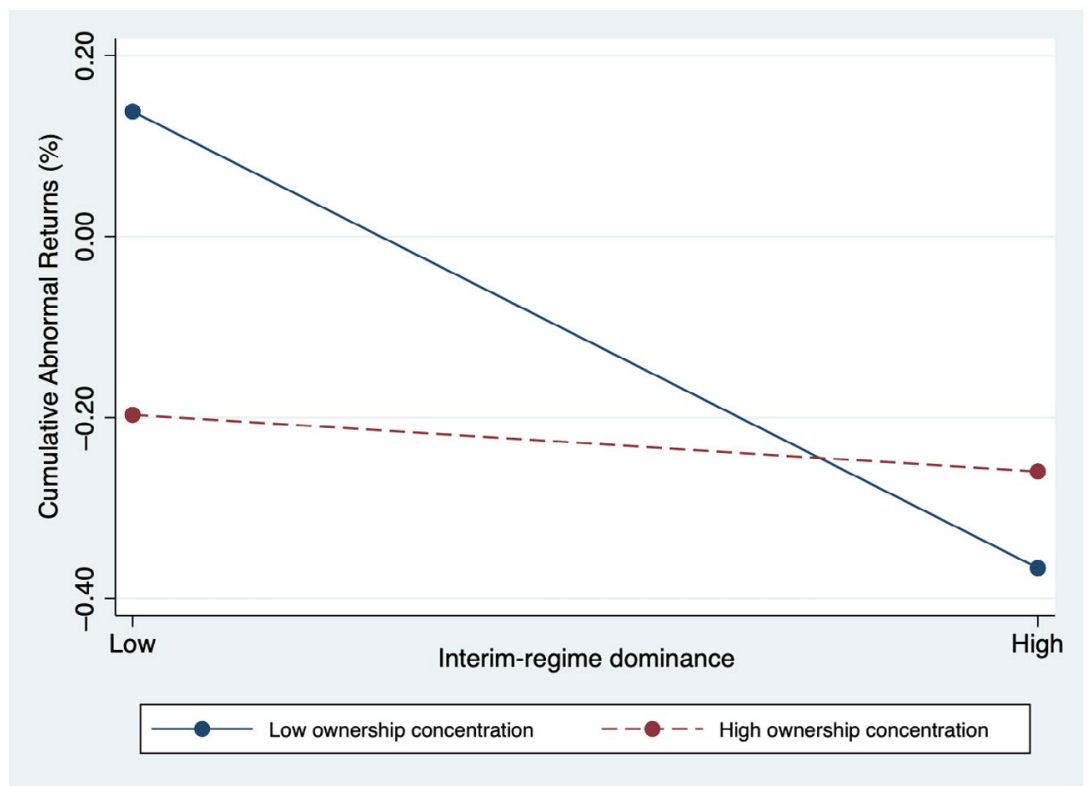

Figure 2. The effect of interim-regime dominance on CARs for firms with low and high ownership concentration, respectively.

in Models 5 and 6 ( $\beta=0.106, p<0.01$ and $\beta=0.110, p<0.001$ respectively). Figure 2 displays this interaction based on Model 6. It shows that the relationship between interim-regime dominance and CARs is substantially negative for firms with relatively dispersed ownership structures, but almost non-existent for firms with concentrated ones. ${ }^{8}$

\section{Supplementary Analyses}

We conducted two additional analyses. ${ }^{9}$ First, we tested our hypotheses for each of the two Egyptian interim regimes separately by splitting our sample into the two respective time periods. Hypotheses 1 and 2c were supported for each regime whereas Hypothesis $2 \mathrm{~b}$ was marginally supported for the second regime $(\beta=-0.050, \mathrm{p}<0.10)$. Hypothesis 2a, moreover, no longer received support, perhaps because of the smaller size of the subsamples in combination with the limited variation in foreign footprint among our sample firms, whose average foreign footprint was just 2.7 per cent.

Second, to gain insight into the boundary conditions of our theoretical framework, we explored whether our hypotheses also hold for the non-interim period in post-Mubarak Egypt. This period has so far seen two regimes, both of which were democratically-elected. A priori we therefore would not necessarily expect to obtain results similar to those for the interim period. Using the same data collection and coding procedures as before, we identified from a total of 4,644 front-page articles published in AMAY, 157 instances of government-related deadly violence that occurred under the two democratic regimes up to June 2015, and consolidated those instances into 97 spells. After running our analysis on this sample, we found that the democratic regimes' dominance 
during these spells had a significantly positive effect on the CARs on Egyptian firms' stocks $(\beta=0.276, \mathrm{p}<0.001)$. In addition, we found no significant moderating effects of a firm's foreign footprint, indebtedness, and ownership structure. In the next section we provide a possible explanation for these findings.

\section{DISGUSSION}

As radical changes in the business environment have become more common in recent decades, management scholars and practitioners have started to show increasing interest in the phenomenon of a 'new normal' (Ahlstrom et al., 2017; El-Erian, 2010; Verbeke, 2018). Some scholars have viewed this new normal as referring to the business environment that has emerged after the 2008 financial crisis, an environment characterized by previously exceptional demand uncertainty and systematically lower productivity growth in developed countries (Clougherty et al., 2019; Storm, 2017).

Around the same time, however, several developing countries witnessed developments that cleared the road for, but not always led to, the rise of another type of new normal, namely a democratic one (Devermont and Temin, 2019). Specifically, since 2010 Arab countries such as Algeria, Egypt, Libya, Tunisia, and - most recently - Sudan saw the rapid demise of their long-standing autocratic rulers and were expected by some to start implementing a system of democratic governance for the first time (Lynch, 2012).

Many of these countries installed interim regimes to initiate and guide the transition to a democratic new normal. However, such regimes may have or develop the private intention to become their country's new autocratic rulers, a possibility that has been proven all too real in several cases throughout history. The emergence of a new normal may thus be highly uncertain, complicating corporate decision-making. Our study sheds light on how investors deal with the uncertainty about the emergence of a democratic new normal during an interim regime's tenure. Enriching the behavioural perspective on investor decision-making with insights on regimes' use of violence, we have proposed that investors interpret higher interim-regime dominance during a given violent event as a signal that the regime has weaker democratic intentions at that time. We therefore advanced the hypothesis that violent events characterized by higher interimregime dominance are received more negatively by the local stock market, a hypothesis for which we found support in an event study of 94 spells of government-related violence in Egypt during the Arab Spring. In addition, we found that negative investor reactions to interim-regime dominance are weaker for firms with larger foreign footprints or more concentrated ownership structures, suggesting that investors perceive firms to be differentially resilient to the more adverse political outlook associated with higher interimregime dominance.

Whereas we found that high dominance displayed by the two Egyptian interim regimes generally triggered negative investor reactions, a supplementary analysis revealed that high dominance shown by the two democratically-elected Egyptian governments generally triggered positive responses from investors. One possible explanation is that, in countries where autocratic rule has collapsed only recently, investors interpret the signal of regime dominance differently across interim and democratically-elected 
governments. Specifically, whereas investors are likely to interpret high dominance by an interim government as a signal of weak democratic intentions, they may interpret high dominance by a democratically-elected government as a signal of the government's capacity to remain in power until the end of its constitutional term (Tyler, 2006). In young democracies such as Egypt, investors may value this capacity positively, since such democracies are fragile and could thus easily slide into anarchy if their government is perceived to be incapable of fending off challenges to its authority (Gills and Rocamora, 1992). This differential investor interpretation of high regime dominance may also explain why we found no significant moderating effects of our three indicators of a firm's resilience to adverse political developments for the period of democratic governance.

\section{Contributions and Implications}

Overall, our conceptual and empirical analysis contributes to three streams of management research. First, it extends the emergent literature on the behavioural perspective of investor decision-making (Bergh et al., 2014; Connelly et al., 2011; Schijven and Hitt, 2012). This literature has argued that, since managers may have intentions that are at odds with shareholder value creation and since they are unlikely to express such intentions, investors will attempt to infer them from crude pieces of public information called 'signals', so as to make more informed investment decisions. Our study contributes to this literature by providing evidence suggesting that investors also use signals to develop insight into the private political intentions of interim governments ruling in the aftermath of authoritarianism. We thus show that, besides using signals to reduce information asymmetries vis-à-vis managers, investors show similar information-seeking behaviour to reduce information asymmetries vis-à-vis external actors whose actions may have a profound effect on firms' future cash flows and, thus, investor wealth. Future studies could further advance the behavioural perspective of investor decision-making by exploring whether investors also use signals to develop insight into other governmental intentions besides democratization, such as a regime's geopolitical or economic intentions (e.g., Katagiri and Min, 2019).

In addition, our study suggests that, besides relying on signals to develop insight into actors' intentions, investors also rely on signals to develop insight into hard-to-observe company characteristics. Specifically, investors seem to use a firm's foreign footprint and its ownership structure as signals of its resilience to deteriorations in a country's political outlook. A possible reason is that investors may distrust managerial statements about that resilience, given that such statements may be overly optimistic, for instance owing to managerial hubris (Hiller and Hambrick, 2005). Future studies could explore whether investors also use signals to develop insight into other latent characteristics of firms, such as the strength of their organizational culture (Barney, 1986).

By contrast, we found no evidence that investors use a firm's indebtedness as a signal of its resilience to adverse political developments. One possible reason is that if a country's political situation deteriorates severely, not only high-debt firms but also low-debt ones may become unable to obtain the capital required to restructure their operations, causing them to be equally vulnerable to bankruptcy. Overall however, our findings provide 
substantial evidence that investors simultaneously scrutinize signals at the regime and firm level to gauge the consequences of local violence for locally listed firms.

Second, our study contributes to the stream of management research on how firms are affected by violence. Some studies within this stream explored the role of the severity of violence. For instance, Hiatt and Sine (2014) found that new ventures in regions with more homicides and kidnappings have lower survival rates, whereas Witte et al. (2017) found that countries with more battle-related deaths receive less greenfield foreign direct investment. Other studies focused on the role of spatial attributes of violent conflict, finding that the proximity and spatial size of such conflict are positively related to the likelihood that a foreign firm exits a country (Dai et al., 2013, 2017). We add to this literature by showing that, after controlling for the severity and spatial attributes of government-related violence, the distribution of the fatalities of such violence across civilians and regime actors substantially influences investors' assessment of the political outlook for local firms and, hence, the market value of these firms. We thus call attention to the affiliation of the fatalities of violence as an additional characteristic of violence that may have important consequences for businesses.

Third, our study contributes to management research on political uncertainty. This research thus far predominantly conceptualized political uncertainty as stemming from a shortage of political constraints on policy change, and explored the corporate relevance of cross-country differences in the level of such constraints (Hendriks et al., 2018; Henisz, 2000; Holburn and Zelner, 2010). We, however, have conceptualized political uncertainty as stemming from the private nature of a regime's political intentions and explored how investors cope with such uncertainty within a given country under a given regime, thus keeping political constraints constant. We specifically explored this question in the context of an interim period because during such a period the political uncertainty concerns the emergence of a new normal for the country and is thus highly consequential to investors' holdings in local firms. Future research could explore how investor or firm behaviour is affected by still other sources of political uncertainty than a shortage of political constraints and the private nature of political intentions. These other sources may include the health condition of an ageing dictator or the secretive nature of ongoing trade negotiations between countries.

Besides making academic contributions, our study also offers valuable insights for officials and managers. Prospective interim officials may benefit from our findings by realizing that higher levels of interim-regime dominance tend to weaken investors' confidence in the prospects of local firms. Interim regimes that repeatedly show high dominance may thus eventually cause the local stock market to collapse and thereby generate an economic crisis, which may undermine the regime's authority and legitimacy. Interim officials with genuine democratic intentions are thus well-advised to consciously decide on their use of force against civilians and exercise restraint as much as possible, so as to minimize the harmful consequences of violence for the local economy.

For managers of firms based in countries that may experience a collapse of autocratic rule, our study suggests a way to limit stock price decreases during the interim period that may follow such a collapse. Specifically, our finding that a firm's foreign footprint causes investors to react less negatively to high interim-regime dominance suggests that managers can limit stock price decreases resulting from such dominance by increasing 
their firm's foreign footprint in anticipation of a possible interim period characterized by high regime dominance. By limiting stock price decreases in this way, managers may be able to successfully issue additional equity when needed, avoid drops in their stock-based personal compensation, and maintain the support of shareholders and the board.

\section{Limitations and Corresponding Suggestions}

Although we have proposed that interim-regime dominance is by definition a crude indicator of a regime's political intentions, our operationalization of the indicator has several limitations that need to be acknowledged. First, unlike prior studies, we were unable to operationalize it as the ratio of civilian fatalities to regime fatalities, owing to the absence of the latter fatalities in several of the analysed spells. Prior studies did not encounter this complication because they focused on larger-scale armed conflicts that resulted in both civilian and regime fatalities. Second, we derived our measure from the front-page news of one Egyptian newspaper. As a result, we may not have captured all instances of government-related deadly violence that occurred during the interim period, for example because some instances may have been reported on subsequent pages or may not have been reported at all owing to editorial choices. Furthermore, although the large majority of investors in Egyptian stocks resides in Egypt and is therefore likely to have obtained news on government-related local violence from our data source, foreign investors may have obtained such news from foreign media. Although the latter media are likely to have covered the more severe instances of government-related violence in Egypt, they may not have reported on instances resulting in only one or a few fatalities. Future studies could therefore attempt to replicate our measure of interim-regime dominance using a variety of news sources, including international ones.

Another limitation is that we did not consider other signals that investors might use to develop insight into an interim regime's political intentions, in addition to its dominance during events of government-related violence. Recent research suggests that investors are capable of cognitively processing a limited set of signals simultaneously, although they typically assign differential weights to them (Drover et al., 2018). Investors might for instance also infer an interim regime's political intentions from mass civilian arrests and the issuance of anti-democratic directives aimed at curbing the influence of parliament or the judiciary. Future studies could explore whether investors also use such pieces of information as signals and, if so, which signal they assign most weight to and how they cope with possibly conflicting signals.

Finally, since our analysis was limited to the two Egyptian interim regimes, and since these regimes were of a different type than those in several other formerly autocratic countries, our results may not be generalizable to all such countries. Specifically, whereas the Egyptian interim regimes were essentially new regimes, the interim regimes in other former autocracies such as Chile and South Korea consisted largely of representatives of the ousted regime (Shain and Linz, 1995). Furthermore, whereas Egypt's interim regimes were appointed by local factions, those of countries such as Iraq and Cambodia were appointed and closely monitored by foreign governments. Future studies could explore whether the dominance displayed by these other types of interim regimes affects investor valuations of local firms differently. 


\section{CONGLUSION}

Our study offers novel insight into investors' use of signals in the context of an interim period following the fall of an autocratic ruler. We show that, in such a context, investors interpret higher interim-regime dominance during a given spell of violence as a signal that the regime has weaker democratic intentions at that time and that a more business-friendly, democratic new normal is therefore less likely to materialize. Furthermore, we show that investors deem firms with a larger foreign footprint or a more concentrated ownership structure more resilient to the adverse political outlook associated with high interim-regime dominance. More generally, by infusing the behavioural perspective on investor decision-making with insights on regimes' use of violence, our study demonstrates the value of cross-fertilization between management and political science research.

\section{AGKNOWLEDGEMENTS}

We would like to thank our editor, Xufei Ma, and three anonymous reviewers for their helpful comments and guidance during the review process. We are also grateful for the constructive feedback provided by participants of the JMS Special Issue Workshop in Lyon. The first author acknowledges the support of the FCT Portuguese Foundation of Science and Technology for project UID/GES/00407/2019.

\section{NOTES}

[1] Amidst the turmoil that accompanied the overthrow of Mubarak, the Egyptian stock market was closed from 27 January to 23 March 2011 . We therefore use the latter date as the starting date of our analysis of how investors react to interim-regime dominance.

[2] 4,155 articles reported news other than instances of violence, whereas 608 reported instances of violence that were not government-related or not deadly.

[3] We obtained qualitatively similar results when we used mean-adjusted expected returns, which are based on the average of a stock's daily returns over the estimation period (Brown and Warner, 1985).

[4] For a given spell of violence, the estimation period is thus the same for all sample firms. Although the estimation period typically contains prior spells of violence, these prior spells were experienced by all sample firms, meaning that the stock market's reaction to them is incorporated in the calculation of the expected returns for all firms. Hence, the fact that for most spells of violence the estimation period contains prior spells is likely to generate merely noise in the resulting abnormal returns rather than firm-specific bias. Moreover, to account for variation in the characteristics of prior spells that are part of the estimation window of a given spell, we also ran our regression models while controlling for (a) the number of these prior spells, (b) the total death toll resulting from them, and (c) the average interim-regime dominance observed for them. These analyses yielded qualitatively similar results.

[5] For 95.3 per cent of the reported instances of violence, their date of occurrence was mentioned in the newspaper article. In 98.4 per cent of these cases, the occurence date was the day before the article appeared, supporting the validity of our approach of using that date as the start date of an event window.

[6] Our dataset has many missing values for firms' foreign footprint, presumably because firms listed on the Egyptian stock exchange are not required to report geographic breakdowns of their revenues. In unreported robustness analyses, we excluded this variable from our models, resulting in a larger sample of 10,552 firm-spell observations. We continued to find a similar degree of support for Hypotheses 1, $2 \mathrm{~b}$, and $2 \mathrm{c}$.

[7] Our sample includes one extremely severe spell of violence, which took place from 14 to 16 August 2013 and generated 343 fatalities, of which 304 were civilians and 39 government forces. To explore whether this outlier drives our results, we also ran our regression models without it. We obtained qualitatively similar results. 
[8] We explored the existence of a curvilinear effect of interim-regime dominance following the procedure outlined by Haans et al. (2016), but found insufficient evidence for the existence of such an effect. We also ran our models using a binary variable coded 1 for spells of violence with interim-regime dominance values above the sample mean and 0 otherwise, and found the same degree of support for our hypotheses.

[9] The results of these analyses are available from the authors upon request.

\section{REFERENGES}

Abadie, A. and Gardeazabal, J. (2003). 'The economic costs of conflict: A case study of the Basque Country'. American Economic Review, 93, 113-32.

Acemoglu, D., Robinson, J. A. and Santos, R. J. (2013). 'The monopoly of violence: Evidence from Colombia'. Fournal of the European Economic Association, 11, 5-44.

Acemoglu, D., Hassan, T. A. and Tahoun, A. (2017). 'The power of the street: Evidence from Egypt's Arab Spring'. The Review of Financial Studies, 31, 1-42.

Ahlstrom, D., Arregle, J.-L., Hitt, M. A., Ma, X. and Qian, G. (2017). Special Issue Call for Papers: Strategy, Innovation, and New Ventures in the New Normal Global Business Landscape. Available at http://www.socad ms.org.uk/special-issue-call-papers-strategy-innovation-new-ventures-new-normal-global-businesslandscape/ (accessed 8 October 2019).

Almazan, A., Banerji, S. and De Motta, A. (2008). 'Attracting attention: Cheap managerial talk and costly market monitoring'. The fournal of Finance, 63, 1399-436.

Alvarez, M., Cheibub, J. A., Limongi, F. and Przeworski, A. (1996). 'Classifying political regimes'. Studies in Comparative International Development, 31, 3-36.

Bae, K.-H., Baek, J.-S., Kang, J.-K. and Liu, W.-L. (2012). 'Do controlling shareholders' expropriation incentives imply a link between corporate governance and firm value? Theory and evidence'. Fournal of Financial Economics, 2, 412-35.

Barney, J. B. (1986). 'Organizational culture: Can it be a source of sustained competitive advantage?'. Academy of Management Review, 11, 656-65.

BBC (2005). Togo's Interim Leader Steps Down. Available at http://news.bbc.co.uk/2/hi/africa/4299731.stm (accessed 8 October 2019).

Bellin, E. (2004). 'The robustness of authoritarianism in the Middle East: Exceptionalism in comparative perspective'. Comparative Politics, 36, 139-57.

Bergh, D. D., Connelly, B. L., Ketchen, D. J. and Shannon, L. M. (2014). 'Signalling theory and equilibrium in strategic management research: An assessment and a research agenda'. Fournal of Management Studies, 51, 1334-60.

Bergh, D. D., Ketchen, D. J., Orlandi, I., Heugens, P. P. M. A. R. and Boyd, B. K. (2019). 'Information asymmetry in management research: Past accomplishments and future opportunities'. Fournal of Management, 45, 122-58.

Berle, A. and Means, G. (1932). The Modern Corporation and Private Property. New York: Macmillan.

Blaydes, L. (2006). 'Who votes in authoritarian elections and why? Determinants of voter turnout in contemporary Egypt'. In Proceedings of the Annual Meeting of the American Political Science Association, Philadelphia, 31 August - 3 September.

Bourgeois, L. J. (1981). 'On the measurement of organizational slack'. Academy of Management Review, 6, 29-39.

Boyd, B. K. and Solarino, A. M. (2016). 'Ownership of corporations: A review, synthesis, and research agenda'. Fournal of Management, 42, 1282-314.

Bromiley, P. (1991). 'Testing a causal model of corporate risk taking and performance'. Academy of Management fournal, 34, 37-59.

Brown, D. S. and Hunter, W. (2004). 'Democracy and human capital formation'. Comparative Political Studies, 37, 842-64.

Brown, S. J. and Warner, J. B. (1985). 'Using daily stock returns'. Fournal of Financial Economics, 14, 3-31.

Busenitz, L. W., Fiet, J. O. and Moesel, D. D. (2005). 'Signaling in venture capitalist-new venture team funding decisions: Does it indicate long-term venture outcomes?'. Entrepreneurship Theory and Practice, 29, $1-12$.

Cameron, A. C., Gelbach, J. B. and Miller, D. L. (2011). 'Robust inference with multiway clustering'. Fournal of Business and Economic Statistics, 29, 238-49. 
Campbell, J. T., Sirmon, D. G. and Schijven, M. (2016). 'Fuzzy logic and the market: A configurational approach to investor perceptions of acquisition announcements'. Academy of Management fournal, 59, 163-87.

Caner, T., Bruyaka, O. and Prescott, J. E. (2018). 'Flow signals: Evidence from patent and alliance portfolios in the US biopharmaceutical industry'. Fournal of Management Studies, 55, 232-64.

Carney, M. and Gedajlovic, E. (2001). 'Corporate governance and firm capabilities : A comparison of managerial, alliance, and personal capitalisms'. Asia Pacific Fournal of Management, 18, 335-54.

Chen, C. J., Li, Z., Su, X. and Sun, Z. (2011). 'Rent-seeking incentives, corporate political connections, and the control structure of private firms: Chinese evidence'. Fournal of Corporate Finance, 17, 229-43.

Cheng, J. and Kesner, I. (1997). 'Organizational slack and response to environmental shifts: The impact of resource allocation patterns'. Fournal of Management, 23, 1-18.

Clougherty, J. A., Duso, T., Seldeslachts, J. and Ciari, L. (2019). 'Transformational strategies and productivity growth: A transformational-activities perspective on stagnation in the new-normal business landscape'. Fournal of Management Studies, 57, doi: 10.1111/joms.12519.

Connelly, B. L., Certo, S. T., Ireland, R. D. and Reutzel, C. R. (2011). 'Signaling theory: A review and assessment'. Fournal of Management, 37, 39-67.

Czinkota, M. R., Knight, G., Liesch, P. W. and Steen, J. (2010). 'Terrorism and international business: A research agenda'. Fournal of International Business Studies, 41, 826-43.

Dai, L., Eden, L. and Beamish, P. W. (2013). 'Place, space, and geographical exposure: Foreign subsidiary survival in conflict zones'. Fournal of International Business Studies, 44, 554-78.

Dai, L., Eden, L. and Beamish, P. W. (2017). 'Caught in the crossfire: Dimensions of vulnerability and foreign multinationals' exit from war-afflicted countries'. Strategic Management Fournal, 38, 1478-98.

Darendeli, I. S. and Hill, T. L. (2016). 'Uncovering the complex relationships between political risk and MNE firm legitimacy: Insights from Libya'. Fournal of International Business Studies, 47, 68-92.

Davenport, G. (1999). 'Human rights and the democratic proposition'. Fournal of Conflict Resolution, 43, 92-116.

Davenport, C. (2007). 'State repression and political order'. Annual Review of Political Science, 10, 1-23.

Dawson, J. F. (2014). 'Moderation in management research: What, why, when, and how'. Fournal of Business and Psychology, 29, 1-19.

De Carolis, D. M., Yang, Y., Deeds, D. L. and Nelling, E. (2009). 'Weathering the storm: The benefit of resources to high-technology ventures navigating adverse events'. Strategic Entrepreneurship Fournal, 3, $147-60$.

Derpanopoulos, G., Frantz, E., Geddes, B. and Wright, J. (2016). 'Are coups good for democracy?'. Research and Politics, 3, 1-7.

DesJardine, M., Bansal, P. and Yang, Y. (2019). 'Bouncing back: Building resilience through social and environmental practices in the context of the 2008 global financial crisis'. Fournal of Management, 45, 1434-60.

Devermont, J. and Temin, J. (2019). 'Africa's democratic moment?'. Foreign Affairs, 98, 131-43.

Doucouliagos, H. and Ulubaşoğlu, M. A. (2008). 'Democracy and economic growth: A meta-analysis'. American fournal of Political Science, 52, 61-83.

Drakos, K. (2010). 'Terrorism activity, investor sentiment, and stock returns'. Review of Financial Economics, 19, $128-35$.

Drover, W., Wood, M. S. and Corbett, A. C. (2018). 'Toward a cognitive view of signalling theory: Individual attention and signal set interpretation'. Fournal of Management Studies, 55, 209-31.

Edmans, A. and Holderness, G. G. (2017). 'Blockholders: A survey of the evidence'. In Hermalin, B. E. and Weisbach, M. S. (Eds), Handbook of the Economics of Corprorate Governance. Amsterdam: Elsevier, 541-636.

Eisenhardt, K. M. (1989). 'Agency theory: An assessment and review'. Academy of Management Reviere, 14, $57-74$.

Eldor, R. and Melnick, R. (2004). 'Financial markets and terrorism'. European fournal of Political Economy, 20, 367-86.

El-Erian, M. A. (2010). 'Navigating the new normal in industrial economies'. In The Per Facobsson Lecture, 10 October 2010. Washington, DC: The Per Jacobsson Lecture. Available at http://www.perjacobss on.org/lectures/101010.pdf (accessed 8 October 2019).

El Nayal, O., van Oosterhout, J. (Hans) and van Essen, M. (2019). 'Ties that bind and grind? Investor reactions to politician appointments to corporate boards'. Fournal of Management, https://doi.org/10.1177/01492 06319869440.

Epstein, L. G. and Schneider, M. (2008). 'Ambiguity, information quality, and asset pricing'. The fournal of Finance, 63, 197-228. 
Faccio, M. and Lang, L. H. P. (2002). 'The ultimate ownership of Western European corporations'. Fournal of Financial Economics, 65, 365-95.

Fan, J. P. and Wong, T. (2002). 'Corporate ownership structure and the informativeness of accounting earnings in East Asia'. Fournal of Accounting and Economics, 33, 401-25.

Francisco, R. A. (1996). 'Coercion and protest: An empirical test in two democratic states'. American fournal of Political Science, 40, 1179-204.

Friedman, E., Johnson, S. and Mitton, T. (2003). 'Propping and tunneling'. Fournal of Comparative Economics, 31, 732-50.

Geddes, B., Wright, J. and Frantz, E. (2014). 'Autocratic breakdown and regime transitions: A new data set'. Perspectives on Politics, 12, 313-31.

George, G. (2005). 'Slack resources and the performance of privately held firms'. Academy of Management fournal, 48, 661-76.

Gills, B. and Rocamora, J. (1992). 'Low intensity democracy'. Third World Quarterly, 13, 501-23.

Guidolin, M. and La Ferrara, E. (2007). 'Diamonds are forever, wars are not: Is conflict bad for private firms?' American Economic Review, 97, 1978-93.

Guttieri, K. and Piombo, J. (2007). Interim Governments: Institutional Bridges to Peace and Democracy? Washington, DC: US Institute of Peace Press.

Haans, R. F., Pieters, C. and He, Z. L. (2016). 'Thinking about U: Theorizing and testing U- and inverted U-shaped relationships in strategy research'. Strategic Management Fournal, 37, 1177-95.

Haleblian, J., Devers, C. E., McNamara, G., Carpenter, M. A. and Davison, R. B. (2009). 'Taking stock of what we know about mergers and acquisitions: A review and research agenda'. Fournal of Management, 35, 469-502.

Hendriks, G., Slangen, A. H. L. and Heugens, P. P. M. A. R. (2018). 'How a firm's domestic footprint and domestic environmental uncertainties jointly shape added cultural distances: The roles of resource dependence and headquarters attention'. Fournal of Management Studies, 55, 883-909.

Henisz, W. (2000). 'The institutional environment for economic growth'. Economics and Politics, 12 , 1-31.

Heugens, P. P. M. A. R., van Essen, M. and van Oosterhout, J. (2009). 'Meta-analyzing ownership concentration and firm performance in Asia: Towards a more fine-grained understanding'. Asia Pacific Fournal of Management, 26, 481-512.

Hiatt, S. R. and Sine, W. D. (2014). 'Clear and present danger: Planning and new venture survival amid political and civil violence'. Strategic Management fournal, 35, 773-85.

Hill, C. W. L. and Snell, S. A. (1989). 'Effects of ownership structure and control on corporate productivity'. Academy of Management fournal, 32, 25-46.

Hiller, N. J. and Hambrick, D. G. (2005). 'Conceptualizing executive hubris: The role of (hyper-)core self-evaluations in strategic decision-making'. Strategic Management fournal, 26, 297-319.

Hitt, M. A., Li, D. and Xu, K. (2016). 'International strategy: From local to global and beyond'. Fournal of World Business, 51, 58-73.

Holburn, G. L. F. and Zelner, B. A. (2010). 'Political capabilities, policy risk, and international investment strategy: Evidence from the global electric power generation industry'. Strategic Management Fournal, $\mathbf{3 1}$, $1290-315$.

Hu, Y. and Izumida, S. (2008). 'Ownership concentration and corporate performance: A causal analysis with Japanese panel data'. Corporate Governance: An International Review, 16, 342-58.

Imbusch, P. (2003). 'The concept of violence'. In Heitmeyer, W. and Hagan, J. (Eds.), International Handbook of Violence Research. Berlin: Springer, 13-39.

Jensen, N. M. (2008). 'Political risk, democratic institutions, and foreign direct investment'. Fournal of Politics, 70, 1040-52.

Kaldor, M. (2013). New and Old Wars: Organised Violence in a Global Era. London: Blackwell.

Katagiri, A. and Min, E. (2019). 'The credibility of public and private signals: A document-based approach'. American Political Science Review, 113, 156-72.

Kim, W. C., Hwang, P. and Burgers, W. P. (1993). 'Multinationals' diversification and the risk-return tradeoff'. Strategic Management Fournal, 14, 275-86.

Kochhar, R. and Hitt, M. A. (1998). 'Linking corporate strategy to capital structure: Diversification strategy, type and source of financing'. Strategic Management fournal, 19, 601-10.

Kogut, B. and Kulatilaka, N. (1994). 'Operating flexibility, global manufacturing, and the option value of a multinational network'. Management Science, 40, 123-39.

Kozikhode, R. (2016). 'Dormancy as a strategic response to detrimental public policy'. Organization Science, 27, 189-206. 
Lake, D. A. and Baum, M. A. (2001). 'The invisible hand of democracy'. Comparative Political Studies, 34, $587-621$.

Lee, S. H. and Makhija, M. (2009). 'Flexibility in internationalization: Is it valuable during an economic crisis?' Strategic Management fournal, 30, 537-55.

Levy, Y. (2010). 'The tradeoff between force and casualties'. Conflict Management and Peace Science, 27, 386-405.

Lewis, P. M. (1994). 'Endgame in Nigeria? The politics of a failed democratic transition'. African Affairs, 93, $323-40$.

Lichbach, M. I. and Gurr, T. R. (1981). 'The conflict process: A formal model'. Fournal of Conflict Resolution, 25, 3-29.

Lynch, M. (2012). The Arab Uprising: The Unfinished Revolutions of the New Middle East. New York: PublicAffairs.

Ma, X., Yiu, D. W. and Zhou, N. (2014). 'Facing global economic crisis: Foreign sales, ownership groups, and corporate value'. Fournal of World Business, 49, 87-100.

Malik, O. R. and Kotabe, M. (2009). 'Dynamic capabilities, government policies, and performance in firms from emerging economies: Evidence from India and Pakistan'. Fournal of Management Studies, 46, 421-50.

Mangena, M., Tauringana, V. and Chamisa, E. (2012). 'Corporate boards, ownership structure and firm performance in an environment of severe political and economic crisis'. British fournal of Management, 23, 23-41.

McGuire, J. W. (1995). 'Interim government and democratic consolidation: Argentina in comparative perspective'. In Shain, Y. and Linz, J. J. (Eds), Between States: Interim Governments and Democratic Transitions. Cambridge: Cambridge University Press, 179-210.

McWilliams, A. and Siegel, D. (1997). 'Event studies in management research: Theoretical and empirical Issues'. Academy of Management fournal, 40, 626-57.

Meyers, L. S., Gamst, G. and Guarino, A. (2006). Applied Multivariate Research: Design and Interpretation. Thousand Oaks, CA: Sage Publication.

Morck, R. K. (1996). 'On the economics of concentrated ownership'. Canadian Business Law Fournal, 26, 63-85.

Morck, R., Wolfenzon, D. and Yeung, B. (2005). 'Corporate governance, economic entrenchment, and growth'. Fournal of Economic Literature, 43, 655-720.

Oetzel, J. M. and Getz, K. A. (2012). 'Why and how might firms respond strategically to violent conflict?'. Fournal of International Business Studies, 43, 166-86.

Oetzel, J. M. and Oh, C. H. (2014). 'Learning to carry the cat by the tail: Firm experience, disasters, and multinational subsidiary entry and expansion'. Organization Science, 25, 732-56.

Oh, C. H. and Oetzel, J. M. (2017). 'Once bitten twice shy? Experience managing violent conflict risk and MNC subsidiary-level investment and expansion'. Strategic Management Fournal, 38, 714-31.

Park, H. D. and Patel, P. C. (2015). 'How does ambiguity influence IPO underpricing? The role of the signalling environment'. Fournal of Management Studies, 52, 796-818.

Pevehouse, J. C. (2005). Democracy from Above: Regional Organizations and Democratization. Cambridge: Cambridge University Press.

Reuters (2012). Islamist Foy as Morsy Elected Egypt President. Available at https://www.reuters.com/article/ us-egypt-election/islamist-joy-as-morsy-elected-egypt-president-idusbre85g01u20120624 (accessed 8 October 2019).

Reuters (2014). Egypt Calls Early Presidential Election as Violence Spreads. Available at https://www.reuters.com/ article/us-egypt-politics/egypt-calls-early-presidential-election-as-violence-spreads-idusbrea0p0gr20 140126 (accessed 8 October 2019).

Richani, N. (2016). 'The political economy and complex interdependency of the war system in Syria'. Civil Wars, 18, 45-68.

Rivoli, P. and Salorio, E. (1996). 'Foreign direct investment and investment under uncertainty'. Fournal of International Business Studies, 2, 335-57.

Rummel, R. J. (1997). Power Kills: Democracy as a Method of Nonviolence. New Brunswick, NJ: Transaction.

Schepker, D. J., Oh, W.-Y. and Patel, P. C. (2018). 'Interpreting equivocal signals: Market reaction to specific-purpose poison pill adoption'. Fournal of Management, 44, 1953-79.

Schijven, M. and Hitt, M. A. (2012). 'The vicarious wisdom of crowds: Toward a behavioral perspective on investor reactions to acquisition announcements'. Strategic Management Fournal, 33, 1247-68.

Seely,J. C. (2009). The Legacies of Transition Governments in Africa: The Cases of Benin and Togo. New York: Palgrave Macmillan.

Shain, Y. and Linz, J. J. (1995). Between States: Interim Governments and Democratic Transitions. Cambridge: Cambridge University Press.

Shleifer, A. and Vishny, R. W. (1997). 'A survey of corporate governance'. The fournal of Finance, 52, 737-83. 
Siegel, J. (2007). 'Contingent political capital and international alliances : Evidence from South Korea'. Administrative Science Quarterly, 52, 621-66.

Stanton, J. A. (2016). Violence and Restraint in Civil War: Civilian Targeting in the Shadow of International Law. Cambridge: Cambridge University Press.

Storm, S. (2017). 'The new normal: Demand, secular stagnation, and the vanishing middle class'. International Fournal of Political Economy, 46, 169-210.

Straus, S. (2012). 'Retreating from the brink: Theorizing mass violence and the dynamics of restraint'. Perspectives on Politics, 10, 343-62.

Stulz, R. M. (2005). 'The limits of financial globalization'. The Fournal of Finance, 60, 1595-638.

Su, Z., Xie, E. and Li, Y. (2009). 'Organizational slack and firm performance during institutional transitions'. Asia Pacific Fournal of Management, 26, 75-91.

Sun, P., Mellahi, K., Wright, M. and Xu, H. (2015). 'Political tie heterogeneity and the impact of shocks on firm value'. Fournal of Management Studies, 52, 1036-63.

The Economist (2019). Sudan and Algeria Overthrow Despots but Not Their Political Systems. Available at https:// www.economist.com/international/2019/04/17/sudan-and-algeria-overthrow-despots-but-not-theirpolitical-systems (accessed 8 October 2019).

The Egyptian Exchange (2014). EGX Annual Report. Available at http://www.egx.com.eg/en/homepage. aspx (accessed 4 January 2019).

The Guardian (2012). Egypt's Generals Wait in the Wings as Battle for Democracy Sours. Available at https:// www.theguardian.com/world/2012/may/05/egypt-generals-wait-wing-revolution-messy (accessed 8 October 2019).

The New York Times (2011). Egypt's Military Expands Power, Raising Alarms. Available at https://www.nytim es.com/2011/10/15/world/middleeast/egypts-military-expands-power-raising-alarms.html (accessed 8 October 2019).

Treisman, D. (2007). 'What have we learned about the causes of corruption from ten years of cross-national empirical research?' Annual Review of Political Science, 10, $211-44$.

Tyler, T. R. (2006). 'Psychological perspectives on legitimacy and legitimation'. Annual Review of Psychology, 57, 375-400.

Ukiwo, U. (2009). 'Violence, identity mobilization and the reimagining of Biafra'. Africa Development, 34, 9-30.

Verbeke, A. (2018). 'The new normal'. In Strategy, Innovation, and New Ventures in the New Normal Global Business Landscape Lecture, 2 July 2018, Lyon, France: EM-Lyon.

van Essen, M., Engelen, P. J. and Carney, M. (2013). 'Does "good" corporate governance help in a crisis? The impact of country- and firm-level governance mechanisms in the European financial crisis'. Corporate Governance: An International Review, 21, 201-24.

van de Vliert, E., Schwartz, S. H., Huismans, S. E., Hofstede, G. and Daan, S. (1999). 'Temperature, cultural masculinity, and domestic political violence'. Fournal of Cross-Cultural Psychology, 30, 291-314.

Westphal, J. D. and Zajac, E. J. (2001). 'Decoupling policy from practice: The case of stock repurchase programs'. Administrative Science Quarterly, 46, 202-28.

Witte, C. T., Burger, M. J., Ianchovichina, E. I. and Pennings, E. (2017). 'Dodging bullets: The heterogeneous effect of political violence on greenfield FDI'. Fournal of International Business Studies, 48, 862-92.

Youngs, R. (2004). 'Democracy and the multinationals'. Democratization, 11, 127-47. 